\title{
COPING BEHAVIOUR AND THE MORATORIUM FOLLOWING SPINAL CORD INJURY
}

\author{
By Thomas D. Stewart, M.D. \\ Harvard Medical School, West Roxbury Veterans Administration Hospital, Department of \\ Psychiatry, Massachusetts Mental Health Center, U.S.A.
}

Abstract. Coping with severe traumatic injury involves three interwoven processesdenial, depression and restitution. Denial and depression are seen as adaptive processes in the appropriate context. A moratorium during the coping process is described; its duration and implications for patient care are discussed.

Key words: Denial and depression; moratorium.

SPINAL cord injury is a stress to any person's capacity to adjust. The changes which this injury produces, both physically and emotionally, can be characterised as the anatomy of catastrophe. The focus of this paper will be on the mechanisms which people use to cope with this stress, and the delay which often occurs before optimal adjustment takes place. The length and significance of this moratorium has received little attention in the literature.

The conceptual model presented here is based on that described by Hamburg and Adams (1967). According to this model of coping behaviour, the tasks faced by our patients consist of 'keeping distress within manageable limits, maintaining a sense of personal worth, restoring relations with significant other people, enhancing prospects for recovery of bodily function, increasing the likelihood of working out a personally valued and socially acceptable situation after maximal physical recovery has been attained'. The achievement of these aims involves a process of three interwoven themes-denial, depression, and restitution-which need not be mutually exclusive. The aim of this coping behaviour is the maintainance of a cohesive sense of self, a goal which may require the passage of considerable time.

The first step to be considered is denial, a vital process in human adjustment. Denial can be defined as a process which blocks the awareness of painful external (non-instinctual) realities. Many of the major losses that occur in living, such as the loss of strength with ageing or the death of a parent, can be predicted. As a result these losses can be dealt with in part by a process called anticipatory grief, a gradual giving up before the loss occurs (Lindemann, 1944). This protective reaction is, of course, not available to the victims of acute injury. Thus denial is needed as a curtain which is lowered to block the patient's perception of his loss. This curtain is gradually lifted as the individual slowly comes to terms with what has occurred. In short, the denial buys time which protects him from being overwhelmed by his injury.

Denial is reflected in fantasy, words, and action (Freud, I966). Phrases like, 'I know this ought to bother me, but ...' are highly characteristic of this defensive reaction. Denial involves a reduced perception of the meaning of what has occurred along with the maintenance of a corresponding fantasy that the loss did not occur. For example, a person may insist that he is going to walk when such hopes are no longer reasonable, or he may acknowledge the fact that he will not walk and yet not experience the associated depression. 
In the context of the early adjustment to traumatic injury, this reaction is both adaptive and protective to the patient. It becomes maladaptive only when it begins to interfere with the realistic efforts and plans that must be made for the patient's care and discharge plans. Continued resistance to making effective plans for remodelling the home post injury is a classic manifestation of maladaptive denial. This denial rarely occurs in isolation since the family often supports and augments the patient's unrealistic feelings and plans. The patient and the family thus jointly affirm their common wish that nothing is wrong. Denial in this sense is a social act which is a concept that has been developed by Weisman and Hackett in their work with the dying (1966). This maladaptive denial takes many forms. It is frequently expressed in action (or inaction) rather than words. The patient may forget to lift himself for pressure relief or forget to empty his bladder on time. This denial of his condition and the care it requires can produce frequent admissions for pressure sores and urinary tract infections.

As the veil of denial lifts, the period of depression is ushered in. Sometimes this transition from denial to depression is revealed in dreams. A 22-year-old man with a $\mathrm{C}_{5}$ level quadriplegia told me of this dream approximately 3 months post injury. He used to be an active hockey player. He dreamed of skating on to the ice fully equipped to be the goalie. Once on the ice he remembered that he was a quadriplegic. He then skated back to the bench to remove his equipment so he could sit and watch the game from the sidelines.

There are multiple causes for depression following spinal cord injury. The injury itself is only the first of possible multiple bodily insults which have depressive as well as physical consequences. There may be recurrent urinary tract infections which can derail the patient's rehabilitation programme just as he begins to make progress. Pressure sores can confine a previously active patient to bed for weeks or months. An ill-timed bowel accident can humiliate the proudest patient.

Bibring (1953) has provided a conceptual model for the mechanisms of depression which may be applied to that encountered in physical disability. Depression is seen as a reflection of the ego's awareness of its inability to generate adequate self-esteem. Nemiah (I957) has pointed out that every physical disability is a blow to self-esteem. Self-esteem is seen by Bibring as consisting of three interrelated self-perceptions which are the sense of being strong, loving and lovable. That spinal cord injury disrupts the patient's capacity to sustain self-esteem is reflected in the fact that only 50 per cent of the spinal cord injured attempt intercourse post injury and approximately 50 per cent return to work in a paying job (Comarr, 1970; Geisler, 1966). The experience created by this feeling of being weak, unlovable and incapable of loving is conveyed by Shakespeare in his introduction to Richard III. The speaker is Gloucester, who suffered from a congenital deformity.

'But I, that am not shaped for sportive tricks,

Nor made to court an amorous looking-glass;

I, that am rudely stamped, and want love's majesty

To strut before a wanton ambling nymph;

I, that am curtailed of this fair proportion,

Cheated of feature by dissembling nature,

Deformed, unfinished, sent before my time

Into this breathing world, scarce half made up,

And that so lamely and unfashionable

That dogs bark at me as I halt by them-

Why, I, in this weak piping time of peace, 
Have no delight to pass away the time,

Unless to spy my shadow in the sun

And descant on mine own deformity.

And therefore, since I cannot prove a lover,

To entertain these fair well-spoken days,

I am determined to prove a villain

And hate the idle pleasures of these days.'

Hopefully, the depression will resolve sufficiently for the progress of psychic repair and restitution to occur. That which can never be again must be given up so that emotional investments can be made in the life possilibilties that remain. The loss of physical and associated social functions needs to be grieved by the patient just as the subjects in Lindemann's study of the Coconut Grove fire needed to mourn the loss of their loved ones (1944). Yet, as Zetzel (1965) has pointed out there is wide variation in people's capacity to carry out this grieving process.

Out of the despair and shock of what has happened, a modified identity must be forged. A paraplegic explained it to me this way. 'My personality before the injury was like a plate-it was shattered; I had to reassemble a new one, but I used a lot of the old pieces.' This analogy conveys the vital blend of change and continuity essential to a sound adjustment. This successful coping will be reflected by the patient's efforts in competitive sports, work, and social relationships. These endeavours help repair his damaged self-esteem.

This process, however, does not occur quickly. It may require years. This period may be considered a moratorium. Erikson has pointed out that such a moratorium often exists before a sense of identity emerges from the confusion of adolescence, thus there is a parallel in normal human developemnt to the delay required to establish a cohesive identity following the disruption of spinal cord injury (Erikson, I963). A clinical example comes from the life of Franklin D. Roosevelt. He was paralysed in I92I. He decided to run for Governor of New York in I928, a full 7 years after he lost the use of his legs. During the intervening period, he invested the bulk of his energy in year-round efforts to walk. His 1924 'Happy Warrior' nominating speech for Al Smith, which was the final scene from the film, Sunrise at Campobella, did not represent a return to the active political life he had known before; instead it was an interlude in an otherwise uncompromising effort to walk. According to Eleanor it was not until 1928 that he made his decision as to whether he would devote himself to his efforts towards recovery or accept his disability in order to play a more active role in the life he was leading' (Lash, I97I). His feelings at this time, as he attempted to cope with his own depression, may have been captured in his first inaugural address in which he spoke to an economically depressed nation, 'The only thing we have to fear is fear itself, nameless, unreasoning, unjustified terror which paralyses needed efforts to convert retreat into advance'. The despair he experienced during this period of adjustment may have been reflected in a poem he cited in a letter written during 1929.

'In the fell clutch of circumstance

I have not winced, nor cried out loud,

And under the bludgeonings of chance,

My head is bloody but unbowed.

It matters not how straight the gate,

How charged with punishment the scroll,

I am the master of my fate,

I am the captain of my soul.' 
The moratorium in the adjustment to spinal cord injury was first described by Cogswell in her study of the socialisation of 36 male paraplegics (I968). She did not, however, quantify its length or develop its implications. It can be viewed from the perspective of sexual and vocational behaviour, both of which bear directly on self-esteem. Felton, in her study of 222 spinal cord injured, did provide some quantification for the moratorium (I965). In her study the unemployed had a mean duration post injury of 6.9 years. On the other hand, the employed averaged being approximately Io years post injury. The difference between these means was significant at the 0.3 level. While the chances for this difference being a random occurrence is appreciable, such evidence does point to the existence of a possible moratorium in the resumption of vocational functioning.

Data from the West Roxbury Veterans Administration Hospital point to a delay in the sexual sphere as well. Sixty-three patients returning for routine annual check-ups were questioned about their sexual efforts. Their mean age was 4I and time after injury was I4 years. Seventy-three per cent had attempted intercourse. Of those who tried, one half were paraplegics and one half quadriplegics. An average of 22 months passed between injury and the first attempted intercourse. For paraplegics the average delay was 23 months and quadriplegics 20 months. Of those who attempted intercourse, 80 per cent were able to enter their partner's vagina with their erection. Further work is being done to determine the effect of marital status and length of hospitalisation on this delay. From these data it is apparent that the injury level has little influence on the resumption of sexual activity. In addition, the high percentage of successful penetrations points to some functional intactness, if sex is resumed.

Patience with ourselves and with those we try to help along with follow-up are the essential reactions to this delay. By routinely expecting the patient to reenter community life and achieve his psychobiological potential soon after discharge, we can add for some a burden of guilt to the difficult task of coping with severe injury. The guilt can derive from the patient's sensing that he has failed our expectations. Indeed, it is often advisable to suggest to the patient that the post discharge period may be quite rocky with some time elapsing before an acceptable adjustment may be made. Follow-up visits provide a chance to see if a moratorium has developed. If so, reassuring the patient that such delays are not rare and that they do not rule out a workable adjustment can be helpful. This reassurance may often need to be couched in a reminder to get moving. To be blunt, a pat on the back and kick in the pants are often necessary.

\section{SUMMARY}

Denial and depression in the appropriate context are natural and adaptive reactions to major traumatic injury. Following such injury there is frequently a moratorium before maximum psychobiological potential is achieved. New data are presented concerning the delay before sexual intercourse is attempted.

\section{RÉSUMÉ}

Placées dans un contexte approprié négation et dépression sont à considérer comme des réactions d'adaption naturelles à une lésion traumatique majeure qui s'accompagne fréquemment d'un moratorium avant qu'un potentiel psychobiologique optimum ne soit atteint. L'auteur presente de nouvelles données sur le laps de temps écoule entre le traumatisme initial et la reprise des rapports sexuels. 


\section{ZUSAMMENFASSUNG}

Selbstverleugnung und Niedergeschlagenheit im passenden Zusammenhang sind natürlich und stellen anpassende Gegenwirkungen zu grossen traumatischen Verletzungen dar. Einer solchen Verletzung folgt oft ein Moratorium bevor das grösste psychobiologische Potential erreicht ist. Neue Ergebnisse werden berichtet bezüglich der Verzögerung des Versuches den geschlechtlichen Verkehr wieder aufzunehmen.

Acknowledgements. I wish to thank Ms Kathy Lampl and Ms Roberta Rosen for their help as research assistants. A grant from the Paralyzed Veterans of America supported the clinical research.

\section{REFERENCES}

Bibring, E. (1953). Affective disorders. In The Mechanisms of Depression. Greenacre, P. (Editor). International Universities Press, New York.

Cogswell, B. E. (I968). Self socialization-the adjustment of paraplegics in the community. F. Rehabil., 34, I I-I3.

Comarr, A. E. (I970). Sexual function among patients with spinal cord injury. Urol. Int., 25, I34-I68.

ERIKSON, E. H. (I963). Childhood and Society. Norton, New York.

Felton, J. S. \& Litman, M. (I965). Study of employment of 222 men with spinal cord injury. Arch Phys. Med. Rehabil., 46, 809-814.

FreUd, A. (1966). The Ego and the Mechanisms of Defense. International Universities Press, New York.

GeIsLER, W. O., JousSA, A. T. \& WyNNE-JoNES, M. (I966). Vocational re-establishment of patients with spinal cord injury. Med. Serv. F. Canada, 12, 689-709.

GutTMANN, SIR Ludwig (I976). Psychological Aspects. In Spinal Cord Injuries. Comprehensive Management and Research. Second Edition, Blackwell Scientific Publications, Oxford.

Hamburg, D. A. \& AdAMS, J. E. (1967). A perspective on coping behavior. Arch. Gen. Psychiat., 17, 277-284.

LASH, J. P. (I97I). Eleanor and Franklin. Norton, New York, p. 3 I8.

LindemanN, E. (1944). Symptomatology and management of acute grief. Amer. $\mathcal{F}$. Psychiat., I0I, I4I-I 48.

Nemiah, J. C. (I957). Psychiatrist and rehabilitation. Arch. Phys. Med. Rehabil., 38, I 43 -I 47.

Weisman, A. D. \& Hackett, T. P. (1966). Denial as a social act. In Psychodynamic Studies on Dying. Levin, S. and Kahana, R. (Editors). International Universities Press, New York.

ZetZeL, E. (1965). Depression and the incapacity to bear it. In Drives, Affects, and Behavior. Schur, M. (Editor). International Universities Press, New York. 